\title{
Regional State Fiscal Policy: Russian and Foreign Experience
}

\section{Pavel Alexeevich Klimenko}

PhD in Economics, associate professor ; pklimenko.81@mail.ru

Natalia Sergeevna Trusova

PhD in Economics, senior lecturer; Trusova-ns@yandex.ru

\section{Olga Sergeevna Prikhodchenko}

\author{
Senior lecturer, Southwest state University, Russia, 380040, Kursk, 50 let Oktyabrya, 94
} olgaprikhodchenko@yandex.ru

\section{Doi:10.5901/mjss.2015.v6n6p436}

\section{Abstract}

Fiscal policy is said to be the most important instrument to regulate social and economic development in regions in most developed countries. Judging by the experience of other countries fiscal policy is very dynamic and should be changeable to function effectively. When regulating regional development it can play a role of a stimulator or limiter of social and ineffective decisions. Fiscal policy is closely connected with macroeconomic processes so that it is one of the elements of macroeconomics. A regional fiscal policy is considered an instrument of economic regulation, which stimulates the economy in a given direction. The article describes the territorial peculiarities of state fiscal policy; the features of the state policy for the economies of different types are defined; the role of state fiscal policy in the country and the regions is validated; the stabilization and structural stances of regional fiscal policy are set; the peculiarities, objectives, and prospects of fiscal policy in the country and in the regions are formulated; the directions in terms of increasing the economic potential of the regions are proposed.

Keywords: fiscal policy, socio-economic development of the region, strategy of the area development, budget management

\section{Introduction}

Policy as a whole is a domain of the state management. Economic policy is an integral part of state policy expressed in the activity of the bodies of state authorities and management aimed at creating a system of economic relations to solve socio-economic tasks and achieve stated objectives.

The state economic policy of the Russian Federation has been constantly changing under the influence of both socio-economic, and institutional and political factors and conditions for the last 20 years. Currently, the state plays a key role in the economy modernization, aimed at achieving sustainable economic growth. Despite the application of the market-based approach for the implementation of the state economic policy, autocratic methods of economy planning play a significant role, weakening the competition in various sectors and spheres of the economy and increasing the tax burden on small and medium-sized enterprises.

The problems of forming and the effective implementation of regional economic policy have been widely discussed in a large number of publications of domestic and foreign scientists.

A great contribution to the development of theoretical problems of regional system management was made by such scientists as E.B. Alaev, Y.V. Vertakova, A.G. Granberg, O.G. Dmitrieva, D.S. Lvov, V.A. Plotnikov, M. Porter, I.E. Risin, Y.S. Polozhentseva, R. Solow, Y.I. Treschevskiy.

The problems of forming and the effective implementation of regional fiscal policy have been widely discussed in a large number of publications of domestic and foreign scientists.

A number of Russian economists, such as Anshin V.M., Afanasyev L.V., Bakaev A.C., Belov N.G., Volkov I.M., Getman V.G., Grachev M.V., Makarov S.N., Lavrov A.M., Malinowska O.V., Tkacheva T.Y. et al. studied theoretical and practical aspects of the program budgeting implementation. Budgeting, accounting, monitoring and analysis of investments and their funding sources covered in the works of such authors as Berens V., Brimson D., Body Z., Gitman 


\section{L.J., Drury K, Kaplan R., Marshall D.F., Richard J., Sharpe U.F, et al.}

The theoretical and methodological (или просто methodical) base of research was performed by results of basic and applied researches in the field of country and regions budget and tax policy. In the course of research the dialectic method, predetermining studying of the phenomena in their continuous development and interrelation, was used. Methods of the structurally functional, economical and statistical analysis, tabular interpretation of statistical information also were applied in the work. The system approach played a special role in justification of the directions and instruments of regional development management.

\section{The Main Part}

Regional economic policy is a set of measures worked out and implemented by the federal and regional authorities to achieve an optimal state of regional meso-economic indicators and to ensure sustainable economic growth. The strategic goal of fiscal policy is defined as an increase of the financial and industrial potential of the region due to the increase of the regional income if there is a stable economic and social growth.

A strategic objective of the regional fiscal policy is improving its own financial and productive potential by regulation and distribution of comprehensive income and expenses. The regional fiscal policy objectives are defined as follows:

- stable functioning of the financial system in the region and balanced development of the economy;

- accumulation of tax revenues between the links of the budget system of the region;

- optimization of expenditure commitments of the region;

- creation of conditions for effective implementation of the powers of public authorities.

Priorities of fiscal policy in the region:

- providing the state with financial resources;

- increasing in tax collection;

- supporting for the financial system and individual sectors in the real economy;

- stimulation of investments into the regional economy;

- evening-out people's income inequalities.

There is an objective necessity for budget and tax policy integration because these directions exist in the indissoluble unity:

- political, as the subjects of the Federation take an active part in formation and implementation of fiscal policy and development of the budgetary strategy;

- economic, as an effective fiscal system provides the regional economic system with reliability and stability, creating conditions for some economic growth.

- social, as effective fiscal policy is able to provide with income growth, decrease tax burden as well as even-out people's income inequalities and implementation of socio-economic programmes (Tkachyova, 2013).

An effective fiscal policy contributes to a favorable climate in the region through additional funds.

Figure1 demonstrates the main objectives of fiscal policy in the region.

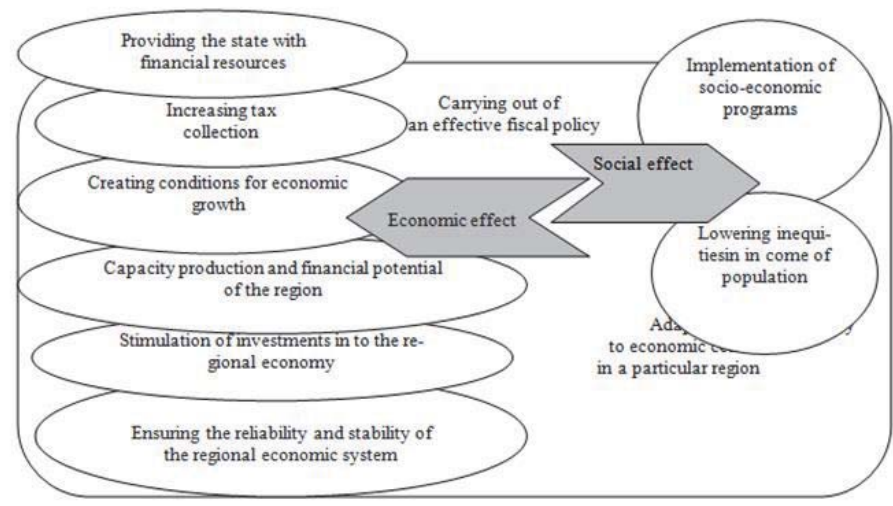

Figure 1 - The main objectives of fiscal policy for socio and economic development of the region. 
The developed mechanism of fiscal policy is shown in Figure 2.

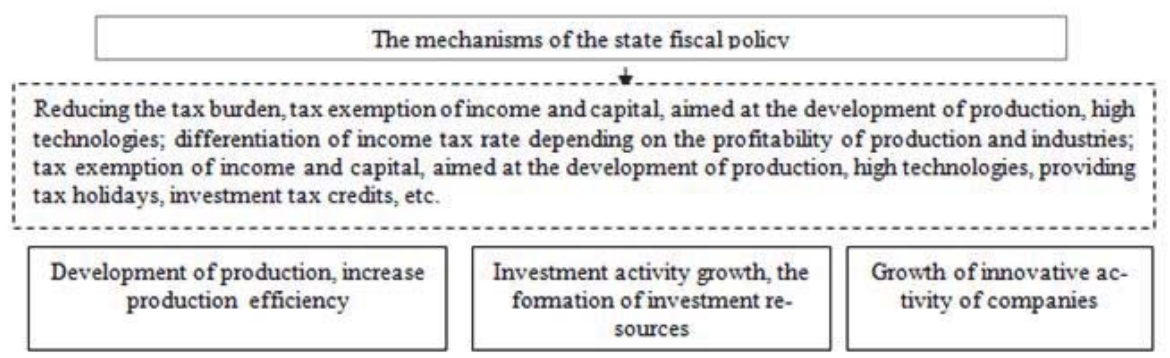

Figure 2 - The mechanism of fiscal policy

Thus, the basic tools of fiscal policy in the region are fiscal, regulatory and stimulating. The fiscal tool is aimed at meeting the public interest. The regulating tool is aimed at reducing profitability of economic entities.

\section{Results}

The main implementation results of the of fiscal policy in Russia in the period up to 2014 are providing with long-term balance and stability of the budgetary system, optimization of the federal budget expenses, improving the tax system, intergovernmental fiscal relations, as well as improving management of government assets and liabilities, and creating "Budget for Citizens".

Nowadays new budgetary tools have appeared. They are long-term federal programs, departmental target programs, state and municipal tasks, government and municipal contracts, new forms of financial support state and municipal services ${ }^{1}$.

One of the priorities in strategic development of the fiscal policy system for 2015 and the planned period of 20162017 is a change of the fixed taxes for the budgets of different levels. The change is aimed at increasing the independence and responsibility of the regions. Revenues of the regional budgets depend on the development of the economy and the distribution of taxes and fees among federal, regional and municipal levels. These taxes and fees are collected in the territory of a subject of the Russian Federation.

According to the Budget Code of the Russian Federation, there is a unitary standard for assessments from federal taxes to regional budgets for all regions of the country. Projects of regional budgets are developed by regional executive authorities (governments, administrations) and then approved by representative authorities of the regions.

The problem for the regions of Russia is a growth of the budget deficit (in more than $60 \%$ of the regions). A number of regions have achieved a budget surplus due to, for example, the growth of tax revenues (St. Petersburg, the Sakhalin region), hard cuts of almost all items of expenditure (Republic of Chechnya), increased transfers from the federal budget (Republic of Chuvashia). The current practice shows a constant decrease in the budget revenue and an increase in expenditure (5\%). The growth rate of income in different regions differs considerably. Following the results of 2013, the Belgorod region revenue growth amounted to $29 \%$ the Moscow region - $35.7 \%$, the Voronezh region - $22.6 \%$, the Kursk region $-8.9 \%$ and the Tula region - $2 \%{ }^{2}$.

The rate of income has hardly exceeded the rate of inflation in 48 regions. In 14 Russian regions, there is even some decrease in total income.

Revenues of the regional budgets increased only for $5 \%$ in 2012, which is below the rate of inflation. The regional budgets revenues remain below the pre-crisis period. Moreover, it is characteristic for 38 subjects of the Russian Federation. The main reason is economic stagnation and (or) insufficient territorial economic development in most regions. Decrease of the consolidated budget revenues depends on the structure of tax revenues. For example, personal income tax is $18 \%$ of revenues, profit tax is $25 \%$, refundable income is $21 \%$, other tax and non-tax revenues are $11 \%$ and

\footnotetext{
${ }^{1}$ Main directions of budgetary policy for 2015 and the planned period 2016 and 2017. URL:http://www.minfin.ru/ru/budget/policy/index. php

${ }^{2}$ Information on performance of the RF subjects and local budgets. URL: http://www.roskazna.ru/byudzhetov-subektov-rf-i-mestnykhbyudzhetov/
} 
property taxes are $10 \%$ of revenues.

The revenue structure of the regional budgets remains stable. The personal income tax is the most important source of their own (tax and non-tax) revenues for most regions. There is a higher proportion of income tax (over 30\%) in developed regions.

However, the amount of profit tax revenues increased only by 3\% in 2012 (in 2011 by 27\%) whereas the profit tax revenues decreased in 26 regions.

If we consider the dynamics of the income tax then the regional economy has worsen. The most deteriorated situation is in the Urals, North-West, Siberia and the Volga region though they are the main industrial regions of the country. The regional economy has worsened in the Far East as well except of Sakhalin. On average, the share of income tax of the regional budgets revenue decreased in 2014 from $27 \%$ to $22 \%$. For comparison, in the crisis of 2009 it was $18 \%$.

With the steady growth of personal income tax decreased revenues of income tax in 26 regions whereas the transfers decreased in 43 regions. The most significant reduction in budget revenues is in the Chukotka Autonomous, the Republic of Karelia, the Murmansk Region and the Krasnoyarsk Kray. It is caused by a significant decrease in profit tax revenues and, at the same time, the amount of transfers from the federal budget. The main reason is a decrease by $20 \%$ of income profit tax a result of the growing crisis in the economy. The problem affected well-developed regions first, whose share of income tax in the budget revenues is higher than the share of other taxes. The second reason is a decrease of transfers by $15 \%$ for subsidized regions.

The structure of the budget expenditures of the consolidated budgets of the subjects is as follows: education 25\%; economy - 19\%; health - 16\%; social policy - 15\%; housing and utilities infrastructure - 11\%; management -6\%; other - 4\%; culture - 3\%; sport - 2\%. According to the Russian Government, own taxes cover less than 15\% of the expenditure needs of the regional and local budgets. The list and the tax base of regional and local taxes are obviously insufficient to finance the expenditures of regional and local character. Moreover, authority to regulate these taxes at the regional and local levels is very limited. It is interesting to note, that tax revenues of the local budgets in the conditions of ownership and regulatory sources in large municipalities occupy a leading place in the structure of revenues.

The Government of the Russian Federation approved the state program "Creation of conditions for effective and responsible management of regional and municipal finances, increasing stability of the budgets of subjects" on the $15^{\text {th }}$ of April, 2014.

The objectives of the programme are supporting the implementation of the regional programmes, which improve the efficiency of budgetary expenditure, and monitoring of the results as well as providing with methodological support and application of stimulating measures in order to improve the management of regional and municipal finances, etc.

The result of the program should be an increase in the number of subjects of the Russian Federation, which should be characterized with a high quality and good management of regional finances: at the $1^{\text {st }}$ step (up to 2015) - up to 74 regions, at the $2^{\text {nd }}$ step $(2016$ - 2020) - up to 78 regions.

The features of the implemented economic policy depend on the type of the economy of the state (Table 1).

Table 1 - The features of economic processes in the different types of economies

\begin{tabular}{|c|c|c|c|}
\hline \multirow[b]{2}{*}{ Characteristic features } & \multicolumn{3}{|l|}{ Economy type } \\
\hline & Centrally-planned economy & \begin{tabular}{|l|} 
Emerging market \\
(developing) economy
\end{tabular} & Market economy (developed) \\
\hline Participants & $\begin{array}{l}\text { State authorities, state } \\
\text { enterprises, cooperative sector }\end{array}$ & $\begin{array}{l}\text { The number of participants may be limited or } \\
\text { unlimited, depending on the presence or } \\
\text { absence of the priorities of the state policy }\end{array}$ & $\begin{array}{l}\text { Unlimited number of } \\
\text { participants, absence of } \\
\text { priorities }\end{array}$ \\
\hline Sources of financing & $\begin{array}{l}\text { State budget, budgets of } \\
\text { territories, equity capital, bank } \\
\text { loans }\end{array}$ & $\begin{array}{l}\text { Equity capital, borrowed and outside funds of } \\
\text { enterprises, state budget, budgets of } \\
\text { territories, foreign investment (with } \\
\text { restrictions) }\end{array}$ & $\begin{array}{l}\text { Equity capital, borrowed and } \\
\text { outside funds of enterprises, } \\
\text { the budgets of all levels, } \\
\text { foreign investment }\end{array}$ \\
\hline $\begin{array}{l}\text { Risks and threats for } \\
\text { economic security }\end{array}$ & Practically no & High risks & Low risks \\
\hline
\end{tabular}

It is possible to analyze the ways of making tax verticals "center - regions" and horizontal link "region - a region" by comparison nationwide tax policies taking into account their regional characteristics (Table 2).

The main world development indicators of financial system of foreign countries are given in table 2 and table 3 . 
Table 2 - Indicators and structure of the regional economy of foreign countries

\begin{tabular}{|c|c|c|c|c|}
\hline Country & USA & Canada & Germany & France \\
\hline State structure & Federation & Federation & Federation & Unitary State \\
\hline Political subdivision & 50 states & 10 provinces $и$ areas & 16 lands & 27 regions \\
\hline Regional potential & high & high & high & high \\
\hline $\begin{array}{l}\text { The level of the regional } \\
\text { fiscal policy implementation }\end{array}$ & high & medium & medium & low \\
\hline Legal entities revenues & medium & low & medium & high \\
\hline Physical persons revenues & high & high & high & medium \\
\hline $\begin{array}{l}\text { The level of ownership } \\
\text { (property) }\end{array}$ & medium & low & high & medium \\
\hline $\begin{array}{l}\text { Characteristics of the tax } \\
\text { policy in the regions }\end{array}$ & \multicolumn{2}{|c|}{$\begin{array}{l}\text { A considerable independence of } \\
\text { subjects of the federation, } \\
\text { independence of decision-making by } \\
\text { regional authorities; lack of attention } \\
\text { to the income redistribution between } \\
\text { the territories for leveling their } \\
\text { budgetary security; providing directly } \\
\text { people in need of targeted assistance; } \\
\text { a clear division of tax powers of the } \\
\text { federal government, state } \\
\text { governments, local authorities }\end{array}$} & $\begin{array}{l}\text { An active regional tax } \\
\text { stimulation of } \\
\text { investments; federal } \\
\text { tax remissions for the } \\
\text { regions; increasing the } \\
\text { role of regional } \\
\text { authorities in tax } \\
\text { revenues distribution }\end{array}$ & $\begin{array}{l}\text { A centralized redistribution of } \\
\text { fiscal resources; regulators } \\
\text { of regional development are } \\
\text { not represented; } \\
\text { strengthening of centralized } \\
\text { redistribution of tax revenues } \\
\text { to the state level }\end{array}$ \\
\hline
\end{tabular}

Table 3 - Central government finances

\begin{tabular}{|l|c|c|c|c|}
\hline Country & Revenue & Expense & Cash surplus or deficit & Debt and interest payments \\
\hline Canada & 17,2 & 17,5 & $-0,2$ & 8,5 \\
\hline France & 42,4 & 46,9 & $-4,6$ & 5,5 \\
\hline United States & 16,6 & 24,0 & $-7,6$ & 15,6 \\
\hline United Kingdom & 36,1 & 42,1 & $-5,5$ & 7,6 \\
\hline Germany & 28,2 & 28,3 & 0,1 & 4,9 \\
\hline Australia & 23,7 & 26,3 & $-3,0$ & 5,8 \\
\hline
\end{tabular}

The main principle of the American model of fiscal federalism is to ensure practical independence of powers in the field of taxation of states and federal government. The tax levels are quite firmly connected with a relatively independent budget; and formed mainly at the expense of its own sources. The federal government, state and territory governments as well as local authorities in the cities, counties, districts, etc. have the right to set their own taxes legally.

The USA is characterized by the decentralization of public finances and by a tax competition between its states. The legislation of the relationship between the states and municipalities are not regulated at the federal level and therefore vary widely within the state. The regional authorities determine a list of potential local taxes on their territory (and sometimes the order of their introduction), whereas the municipalities make decisions on the introduction of these taxes. At present more than 500 federal targeted programs of financing the states and counties through targeted transfers are implemented in the USA. In general, the transfers from the federal budget cover about $20 \%$ of the state expenditure and, above all, are used to improve living standards in the USA. The local authorities regulate a significant part of government expenditures related to the financing social needs of the local economy and the administrative apparatus (Vertakova, Plotnikov, 2013).

Thus, separation of tax sources and broad powers of states and municipalities in the area of taxation laid the foundation for the vertical balancing of the American budgetary system.

The Canadian fiscal federalism model is quite similar to the American one. Its provinces have the right to make laws on all regional and local matters; they are free to determine their own tax policy. Provinces and municipalities have the right to add their rates to the basic federal rate of the total taxes. The main instruments of financial equalization of territories in Canada are inter-budgetary transfers. Tax revenue transfers to municipalities are not widely available. In Canada, the criterion for transfer allocation is a degree of the financial security lag of provinces from the national average calculated level. 
A fundamental principle of the federal structure in Germany should be considered a principle of subsidiarity in the distribution of competences between the Federation and the Lands.

In the German model of cooperative federalism, the profitable part of all level budgets is formed mainly at the expense of certain legal assessments (interest) from the federal taxes. The basic principle is differentiation of the federal taxes into revenues in accordance with independent regional budgets. Thus federal taxes come into the federal budget, the budgets of the Federation (lands and cities) and the local budgets in different proportions. The main instrument of the vertical balancing is the distribution of VAT revenues between the federal and the total budget of the land (Vertakova, Polozhentseva, Klevtsova, 2014).

A modern German model of fiscal federalism is focused on partnership and active policy of the federal center for vertical and horizontal balancing of territorial entities in which fiscal capacity is less than the average level.

In most countries, local revenues are formed from more than one tax source (Table 4).

Table 4 - The revenue structure of local budgets of federal states in 2013

\begin{tabular}{|l|l|c|c|c|c|c|c|}
\hline \multicolumn{2}{|l|}{} & the USA & Canada & Australia & Germany & Switzerland & Russia \\
\hline Non-tax revenues & Share in income,\% & 24 & 19 & 55 & 18 & 29 & 10 \\
\hline Transfers & Share in income, \% & 37 & 42 & 9 & 49 & 13 & 60 \\
\hline Taxes & Share in income, \% & 39 & 39 & 36 & 33 & 58 & 30 \\
\hline
\end{tabular}

In the some states, taxes provide for $65-75 \%$ of revenues into the local budgets, whereas the inter-budgetary transfers cover no more than 10-20\% ((Iceland, Sweden). In other countries, the situation is quite opposite (the Netherlands, Greece, United Kingdom). In most unitary states, taxes make up $35-45 \%$ of the local budget revenues. The role of transfers from of the above-mentioned budgets differs because of the value of non-tax revenues. In federal states about $35 \%$ of the revenues of municipalities make up taxes (Table 5).

Table 5 - Comparative characteristics of intergovernmental relations of federal states in 2013

\begin{tabular}{|l|l|c|c|}
\hline \multirow{2}{*}{ State } & Characteristics of intergovernmental relations & \multicolumn{2}{|c|}{ Taxes; \% } \\
\cline { 2 - 4 } Australia & $\begin{array}{l}\text { - centralized federation } \\
\text { - low role of the local authorities }\end{array}$ & 36 & 0.9 \\
\hline The Russian Federation & $\begin{array}{l}\text { - tax legislation is centralized } \\
- \text { - a high degree of financial balancing } \\
\text { - minimum tax powers of the local authorities }\end{array}$ & 30 & 1.79 \\
\hline Germany & $\begin{array}{l}\text { - a high degree of financial balancing } \\
\text { - tax legislation is centralized } \\
- \text { sharing of the main types of taxes }\end{array}$ & 33 & 2.9 \\
\hline Canada & $\begin{array}{l}\text { - financial balancing through transfers } \\
- \text { the right to charge for only direct taxes at the sub-national level }\end{array}$ & 39 & 3.1 \\
\hline the USA & $\begin{array}{l}\text { - tax competition between the states } \\
- \text { taxation of the same objects at different levels of authority }\end{array}$ & 39 & 4.1 \\
\hline Switzerland & $\begin{array}{l}- \text { the right to charge for only direct taxes at the sub-national level } \\
- \text { additional local tax rates to the regional ones }\end{array}$ & 58 & 4.7 \\
\hline
\end{tabular}

The structure of tax revenues in the Russian Federation is similar to the German one, because both federations give a priority to the financial balancing of territories.

\section{Conclusion}

Fiscal policy determines the sources of the formation of state treasury, the formation of the tax system and the state budget. Using fiscal policy as a regulator (creating incentive, rewarding or disincentive, restrictive conditions) it is possible to influence the activity of the market entity by means of rewarding or imposing restrictions, or through the implementation of tax control.

An effective fiscal policy contributes to a favorable climate in the region through additional funds. There are some mechanisms to stimulate economic activity of the subjects of the Russian Federation. They are providing for tax 
incentives, guaranteeing reimbursement of credits, received by economic entities in commercial banks; establishment of the procedure to use land lots or take possession of them; to have interest in financing from the budget of individual investment projects.

Development of the regional investment potential and the possibility of qualitative modernization of the regional industrial complex depend on the methods of fiscal policy.

Thus, the paper provides evidences for the necessity of the state economic policy transformation as a prerequisite for the formation of the innovative economy in Russia, the necessity of forming innovative regions of Russia on the basis of the use of the competitive advantages of the region.

This modernization shall result in the economic growth and increase in industrial production at the macro level and the formation of innovative infrastructure, modern forms of industrial and territorial organization of production (science par $\mathrm{ks}$, technopolises, clusters) at meso-level.

\section{References}

Tkachyova, T.Yu. (2013). Modern tendencies of fiscal security of the region. News of Southwest state university. Economic and jurisprudence, 2-47, 55-61.

Vertakova, Y., Plotnikov, V. (2013). Russian and foreign experience of interaction between government. World Applied Sciences Journal. Vertakova, Y., Polozhentseva, Y., Klevtsova, M. (2014). The development of regional cluster-oriented policy: russian and foreign practice. All Rights Reserved by the SGEM International Multidisciplinary Scientific Conferences SOCIAL SCIENCES and ARTS. Published by STEF92 Technology Ltd., 1 “Andrey Lyapchev" Blvd., 1797 Sofia, Bulgaria, p.399-406

The World Bank group. URL: http://www.worldbank.org; authors' calculations 